\title{
TRANSFORMASI DAN PEMBERDAYAAN \\ UMAT BERBASIS MASJID: \\ Studi Pada Masjid Nurussa'adah Salatiga
}

\author{
M. Zulfa \\ Institut Agama Islam Negeri (LAIN) Salatiga \\ mzulfa76@yahoo.com
}

\begin{abstract}
This study aimed to answers about the functionality of Nurus Sa'adah Mosque in the process of transformation and empowerment of community, both on the activities of "mahdhah" and social activities. This study was designed with qualitative descriptive approach. Data analysis was presented by describing the data that has been selected at reductive and draw a phenomenon that occurs on understanding theories that exist both on the theory of the sociology of religion, as well as theories related to social dynamics and social motivation. The results showed that the mosque Nurus Sa'adab, has been able to realize its function as an agent of transformation and empowerment for his congregation. Empowerment is actualized in mahdhah and social activities.
\end{abstract}

Keywords: Empowerment, mosque, mahdhah

\begin{abstract}
Abstrak
Penelitian ini bertujuan untuk memperoleh jawaban tentang seberapa jaub fungsi Masjid Nurus Sa'adah dalam proses transformasi dan pemberdayaan umat, baik, pada aktifitas ibadah mahdhah maupun aktifitas sosial keagamaan. Penelitian ini didesain dengan corak pendekatan yang bersifat kualitatif deskriptif. Analisis data yang digunakan bersifat deskriptif dengan memaparkan data yang telah diseleksi secara reduktif dan menggambar fenomena yang terjadi dengan memahami berdasarkan teori-teori yang ada baik dari teori sosiologi agama, maupun teori yang berkaitan dengan dinamika sosial dan motivasi sosial. Hasil penelitian menunjukkan, bahwa Masjid Nurus Sa'adah, ternyata telah mampu mewnjudkan fungsinya sebagai agen transformasi dan pemberdayaan bagi jamaahnya. Pemberdayaan itu teraktualisasi dalam ibadah mahdhah manpun aktifitas sosial keagamaan .
\end{abstract}

Kata Kunci: Pemberdayaan, jamaah masjid, ibadah mahdhah 


\section{Pendahuluan}

Dari segi bahasa, masjid berarti tempat untuk sujud atau untuk mengerjakan salat. Namun secara istilah lalu berkembang sebagai tempat ibadah. Ibadah, diartikan sebagai pengabdian. Dengan demikian masjid berarti tempat pengabdian. Dalam perkembangan sejarah keberadaan dan fungsi masjid bukan saja untuk kepentingan melakukan ritual salat saja, tetapijuga untuk kepentingan-kepentingan lain yang bersifat sosial. Masjid dalam sejarah pendidikan Islam, telah berfungsi pula sebagai tempat atau media pendidikan. Masjid juga digunakan untuk pelayanan, penerimaan dan penyaluran zakat fitrah serta zakat maal. Kini masjid pun telah berkembang bangunan dan komplek areanya menjadi berfungsi untuk pelayanan kesehatan (poliklinik kesehatan) bahkan dibebetrapa masjid besar juga dibangun kegiatan ekonomi dan koperasi. Karena itu kini masjid sekaligus menjadi kompleks Islamic Centre.

Fenomena yang muncul, terutama di kota-kota besar memperlihatkan banyak masjid telah menunjukkan fungsinya sebagai tempat ibadah, tempat pendidikan, dan kegiatan sosial lainnya (Ayu B dkk, 2001: 8). Bahkan masjid-masjid di pedesaan dan masjid-masjid yang dikelola secara tradisionalpun kini sudah mulai merambah pada kegiatan di luar peribadatan, seperti misalnya digunakan untuk pendidikan al-Qur'an, yang kini di kenal dengan TPQ, atau Madrasah Diniyah, tempat majelis Ta'lim atau pengajianpengajian, baik pengajian ibu-ibu, bapak-bapak, remaja ataupun pengajian umum. Bahkan untuk menambah pengetahuan umum, sering digunakan oleh para remaja masjid sebagai media untuk memperdalam pengetahuan umum yang dirasa masih kurang dari pelajaran yang diselenggarakan di lembaga-lembaga pendidikan formal, seperti bahasa Inggris, matematika, fisika dan lain-lain. Tidak jarang pula masjid digunakan untuk menempa anak-anak atau remaja mengisi kegiatan liburan dengan bentuk pesantren kilat dan sebagainya.

Sementara masjid-masjid di kota-kota besar, seperti masjid al-Azhar, Kebayoran Baru Jakarta, dibangun pula aula untuk pertemuan-pertemuan, untuk pesta perkawinan, kantor kegiatan organisasi kepemudaan, perpustakaan, klinik kesehatan, tempat, 
atau kantor redaksi majalah, pusat kegiatan seni seperti drumband, kegiatan olah raga, seni bela diri, kantor majelis ulama. Begitu pula halnya masjid-masjid lainnya seperti masjid Istiqlal, masjid Sunda Kelapa dan lain sebagainya.

Berkaitan dengan fungsi masjid untuk memberdayakanjamaah di Salatiga, menarik untuk dikaji kegiatan Masjid Nurus Sa'adah Dliko Indah. Masjid di perumahan Dliko Indah ini mempunyai kegiatan yang berkembang dengan cukup baik. Masjid yang semula dibangun dengan bantuan PP Muhammadiyah, telah menunjukkan perkembangan yang cukup signifikan. Masjid ini berada di atas tanah yang merupakan bantuan dari Pemerintah Kabupaten Semarang. Dengan tanah yang luasnya hanya 414 M2 ini telah berkembang dan memiliki tanah tambahan sekitar 575 M2, yang dibeli dengan sistem wakaf bersama para jama'ah. Tanah seluas kurang lebih 575 M2 itu kini sedang dibangun Islamic Centre, dengan rencana beaya sekitar lima milyar rupiyah. Perkembangan yang relatif baik ini ternyata tidak bisa lepas adanya motivasi yang dibangun oleh takmir dan para penceramah (muballigh) yang pada umumnya berasal dari IAIN Salatiga. Terdapat kurang lebih 30 orang dari dosen IAIN. Dengan sistem terjadwal untuk kegiatan Kuliah Subuh dan Tarawih di bulan Romadlon dan khutbah jumat, maupun pengajian juma't yang diberikan oleh para dosen IAIN secara bergilir dan Kuliah Subuh tiap hari Ahad, telah membangkitkan kebersamaan dan semangat berinfaq dari para jamaah masjid maupun saudara dan relasi para jamaahnya. Hal ini Nampak ketika membeli tanah seluas 575 M2, telah bisa dirampungkan dalam waktu kurang dari satu bulan dengan sistem wakaf bersama secara jama'ah. Bahkan dari infaq jama'ah tersebut telah menyisakan anggaran sebesar 200 juta rupiah sebagai awal bangunan Islamic Centre tersebut. Semangat atau ghirah berinfaq dan bersodaqoh itu nampak dilakukan dalam suasana fastabiqul khairat yang murni. Suasana seperti ini yang mendorong peneliti untuk mengungkap, latar belakang apa sebenarnya yang menimbulkan motivasi para jamaah untuk meningkatkan ibadah, baik ibadah mabdhah maupun maupun ibadah sosial seperti infaq dan sodaqoh dan sebagainya. 


\section{Agama dan Misi Perubahan}

Sebagaimana digambarkan oleh Comton dan Galaway yang mengetengahkan pendapat Lippit dan Westley dalam Social Work and Processes (1979:109) berpendapat, bahwa dinamika perilaku masyarakat yang membentuk kebudayaan khas yang memantulkan adalah karena kebutuhan yang sama akan tujuan yang hendak dicapai yang dikokohkan oleh hubungan fungsional dan pilihan sosial yang teruji serta generalisasi kepentingan yang lebih transformatif dan stabil untuk dijadikan norma-norma kehidupan dalam masyarakat (Saebani, 2007: 2).

Menurut sosiolog, fungsi transformatif yang dikakukan dalam aktifitas keagamaan berarti mengubah bentuk kehidupan masyarakat lama dalam bentuk kehidupan baru (Hendropuspito, 1983: 56). Nilai-nilai yang telah diperoleh oleh para jamaah itu telah mengubah kesetiaan jamaah dari kebiasaan lama ke dalam kebiasaan baru dan membentuk kepribadian. Hal itu dapat diidentifikasi para jamaah yang dulunya tidak atau jarang sekali berjamaah kini telah rajin mengikuti salat wajib dengan berjamaah, yang dulu jarang sekali mengikuti pengajian, kini telah banyak dan selalu mengikuti pengajian-pengajian rutin yang diselenggarakan oleh Takmir Masjid. Sebagai contoh yang sederhana dalam fenomena ini dapat dilihat kalau dulu sebelum mendapat pencerahan, orang cenderung mudah konflik atau mudah renggang dengan sesama tetangga, kini setelah pencerahan terjadi fenomena rukun, saling komunikasi dan silaturrahmi, bahkan kebersamaan dan akrab selalu dan sering terlihat diantara anggota masyarakat, terlebih dalam acara-acara kegiatan keagamaan baik ibadah mahdhah, maupun ibadah ghairu mahdhah, terlebih dalam keterlibatan kepanitiaan. Kebersamaan itu terlihat dalam acara-acara pengajian-pengajian, penerimaan dan penyaluran zakat mal dan fitrah, penyembelihan dan penyaluran hewan qurban, peringatan-peringatan hari-hari besar Islam, kegiatan pelatihan manasik haji maupun walimatussafar, maupun walimatul urusy. Dari realitas ini dapat disimpulkan bahwa proses transformasi atau perubahan kehidupan ke arah yang lebih positif dan lebih baik sangat baik dilakukan dengan media masjid sebagai basis pembinaan umat. 
AjaranAgamamemilikipengaruhyangbesardalammenyatukan persepsi kehidupan masyarakat tentang semua harapan hidup. Sebagai salah satu arah kehidupan sosial yang proses pemolaannya lebih sistematis dan mendarah daging. Dalam pemolaan, perilaku sosial agama memasuki hati nurani manusia sehingga akal pikiran utama mencari makna hidup belum sempurnan apabila substansi ajaran agama tidak dijadikan rujukan terpenting secara etimologis ataupun aksiologis (Hamka, 1989:13, dalam Saebani, 2007:2).

Sebagaimana diungkapkan oleh sosiolog D. Hendro Puspito (1983) bahwa Agama menyampaikan ajarannya dengan perantaraan petugas-petugasnya baik di dalam upacara (perayaan) keagamaan, khotbah, renungan/meditasi, pendalaman rohani dan lain-lain, maupun di luar perayaan liturgis. Realitas ini dapat disimpulkan bahwa dengan berbasis masjid, motivasi untuk mewujudkan pribadipribadi yang unggul dan berkualitas khususnya dalam amaliah keagaaman, dapat dilakukan dengan lebih efektif.

\section{Masjid sebagai Basis Transformasi dan Pemberdayaan Umat.}

Secara luas masjid seharusnya harus bisa berfungsi secara optimal, bukan saja sebagai tempat ibadah, tetapi juga kegiatan-kegiatan lain. Masjid sebagai pusat dakwah, dan pendidikan sebagaimana dapat digambarkan sebagaimana berikut ini:

1. Sebagai tempat ibadah shalat, zikir dan i'tikaf. Sejak dahulu sahalat berjamaah dan shalat jum'at dipusatkan di masjid. Begitu pula majelis-majelis zikir secara berkelompok dan i'tikaf di bulan Ramadhan.

2. Tempat kegiatan dakwah dan pendidikan.Dakwah bukan hanya dalam bentuk khotbah tetapi juga berupa ceramah, diskusi dan majelis taklim. Sedangkan pendidikan yang harus dikembangkan di masjid adalah : pengajian dasar al-Qur'an dan pengajian lanjutan (tajwid dan lagu) serta pembacaan kitab-kitab agama seperti kitab kuning.

3. Perpustakaan dan taman bacaan.Hal ini perlu diadakan untuk meningkatkan semangat membaca. 
4. Bimbingan dan penyuluhan agama (guidance and counceling). Media ini untuk membantu para remaja atau pemuda yang mengalami masalah mental atau spiritual, sebagai akibat dari polusi budaya dan pengaruh negatif kehidupan modern, seperti narkoba, HIV/AIDS dll. Dewasa ini dirasakan perlunya ada pembimbing spiritual dari para ulama untuk mengatasi masalah-masalah kejiwaan yang dialami oleh pemuda/remaja kita.

5. Pembinaan remaja masjid. Remaja masjid harus dibina dan dikader sebagai generasi pelanjut, baik dalam pengelolaan masjid seperti menjadi protokol masjid, muadzin, imam shalat maupun untuk mengembangkan bakat dan minat mereka dalam organisasi, olahraga dan seni budaya, termasuk seni bela diri ataupun latihan pengembangan tenaga dalam.

6. Pengelolaan zakat. Dengan lahirnya UU No.38 th.1999 tentang pengelolaan zakat, maka seharusnya masjid-masjid memiliki pengurus tetap yang menangani zakat; jadi bukan hanya sebagai panitia seperti selama ini sebab panitia sifatnya hanya sementara. Zakat harus dikelola secara profesional dan berkesinambungan.

7. Pembinaan calon haji. Menurut pengalaman dan berbagai informasi, jemaah haji Indonesia sangat rendah pengetahuannya tentang manasik haji. Seharusnya hal ini diatasi dengan cara pembinaan calon haji di masjid.

8. Pembinaan kegiatan sosial, Kesehatan Lingkungan dan lainlain, seperti: a) pemberian santunan fakir miskin melalui ZIS. b) pembinaan masyarakat dhuafa' seperti tukang becak c) penyelenggaraan pengurusan jenazah (memandikan, mengkafani, dan menshalatkan). Untuk itu masjid perlu ada ruang khusus tempat memandikan jenazah, keranda/usungan dan mobil jenazah. Bahkan di masjid perlu disediakan kain kafan dan tenaga yang mahir manangani tugas memandikan, mengkafani, menshalatkan dan menguburkan.

9. Pembinaan ekonomi lemah, Pengusaha kecil, pedagang kaki lima, penjual di pasar dan wiraswastawan perlu diberi pembinaan dengan jalan pemberian informasi pasar, kiat-kiat berusaha, tatacara memperoleh kredit di bank dan lain-lain yang dapat dilakukan melalui masjid atau membangun Koperasi Masjid. 
10. Pembinaan administrasi dan keuangan masjid. Managemen masjid harus dilakukan dengan baik, amanah, transparan dan tertib. Kepercayaan jamaah terhadap Pengurus Masjid sangat menentukan keberhasilan suatu masjid dalam melaksanakan programnya. Karena itu pembinaan administrasi dan keuangan harus dikelola dengan baik dan dilakukan penyempurnaan terus menerus (Diakses dari internet: http://sulsel.kemenag.go.id/ index.php?a=artikel\&id=13634 Senin, 27 April 2015).

Darike10 peran masjid sebagaimana dikemukakan diatas, Masjid Nurus Sa'adah telah melaksanakan sebagian besar, bahkan kini di tambah dengan rencana pembangunan Islamic Centre sebagai pusat kegiatan sosial budaya. Masjid Nurus sa'adah kini telah mengalami perkembangan yang cukup signifikan sehingga dapat mengembangkan kesalehan personal maupun kesalehan sosial. Masjid Nurus Sa'adah memiliki rencana kegiatan, ataupun visi dan misi, agar masjid mempunyai perkembangan fungsi, agar kegiatannya bisa dikaitkan dengan kebutuhan jama'ah dari berbagai bidang kehidupan, seperti ibadah, kegiatan pendidikan, kesehatan, social dan ekonomi. Untuk itu biasanya rumah ibadat membuat bangunan lain disekitarnya. Untuk pelayan kesehatan dan pendidikan jamaah dan masyarakat luas secara umum. Kegiatan pelayanan pendidikan, kesehatan, kesejahteraan social, bahkan kesenian dan olah raga, karena ia meruppakan sarana dakwah yang efektif dan mendasar (Agus, 2003: 119).

Diantara penelitian terdahulu yang pernah dilakukan adalah Penelitian yang dilakukan oleh Parlindungan Siregar, Badan Penelitian dan Pusdiklat Lektur Khazanah Keagamaan Kementerian Agama RI tahun 2010, dalam penelitian ini dengan bermula melihat gaya arsitektur, peneliti menyimpulkan bahwa masjid yang dibangun pada tahun 1786 ini oleh seorang Kapiten Cina di Batavia ini merupakan potret akulturasi masyarakat muslim. Karena pada bangunannya ini ditemukan unsur-unsur budaya Jawa, Arab dan Eropa dan juga Cina. Dan ini membuktikan bahwa telah terjadi kerukunan antara umat Islam dengan umat-umat lainnya. Titik tekan penelitian ini adalah Penelitian sejarah dan kerukunan umat beragama pada 
abad XVIII.Masih banyak penelitian-penelitian masjid yang pada umumnya meneliti sejarah dan nilai-nilai historis, serta aktifitas pemakmuran masjid, juga ada beberapa yang meneliti tentang peran masjid terhadap masyarakat sekitar, serta peran masyarakat terhadap pengembangan dan peningkatan fungsi masjid.

\section{Metode Penelitian}

\section{Jenis Penelitian}

Jenis penelitian ini adalah penelitian deskriptif-kualitatif dengan pendekatan fenomenologis. Dimaksud penelitian deskriptifkualitatif fenomenologis adalah menggambarkan perilaku yang terjadi pada jamaah masjid nurus sa'adah dalam melaksanakan ibadah mahdah serta aktifitas lainnya berkait dengan kegiatan social yang menjadi program dan kegiatan masjid, serta mengungkap motifmotif yang melatar belakangi perilaku tersebut. Suprayogo (2003) mengungkapkan: fenomena agama menerapkan metododologi ilmiah dalam meneliti fakta relegius yang bersifat subyektif seperti pikiran-pikiran, perasaan-perasaan, ide-ide, emosi-emosi, maksud-maksud, pengalaman, dan sebagainya dari seseorang yang diungkapkan dalam tindakan luar (perkataan dan perbuatan)

\section{Teknik Pengumpulan Data}

Ada lima teknik pengumpulan data yang peneliti gunakan, yakni teknik interview mendalam atau indepth interview, observasi partisipant, dokumentasi dan FGD (focus Group Discussion). Dengan demikian, berasarkan fakta yang ingin diungkap peneliti menggunakan trianggulasi teknik, yaitu untuk menguji kredibilitas data dilakukan dengan cara mengecek data kepada sumber yang dengan teknik yang berbeda (Sugiyono, 2010: 274). Disamping itu, untuk mendasari secara teoritik phenomena yang terjadi peneliti juga menelusuri kajian teoritik yang peneliti duga sebagai teori yang mendasari perilaku jamaah dengan melakukan studi kepustakaan.

Interview mendalam digunakan untuk mengungkap, motivasi jamaah masjid Nurus Sa'adah dalam mengikuti kegiatan-kegiatan yang diselenggarakan oleh takmir masjid baik yang berkaitan dengan 
aktifitas ibadah mahdhah seperti salat-salat wajib, maupun salat sunnat seperti salat tarwih, salat tahajud dan sebagainya. Sementara teknik observasi peneliti gunakan untuk melihat dan mencrossceking realita di lapangan (masjid) untuk melihat fenomena yang terjadi secara empirik. Dan karena peneliti juga sebagai anggota takmir sekaligus juga peserta aktifitas bersama dengan jamaah yang lain, maka obeservasi yang penulis lakukan adaalah obeservasi partisipan atau obeservasi berperan aktif. Spradly (1980) dalam Suprayogo (2003) mengatakan dalam observasi model ini, peneliti dapat memainkan berbagai peran yang dimungkinkan dalam situasi sesuai dengan kondisi subyek yang diamati. Cara ini dilakukan semata untuk dapat mengakses data yang diperlukan bagi penelitiaannya. Sementara dokumentasi dan FGD peneliti gunakan untuk mengukur validitas data yang peneliti peroleh lewat interview. Dengan demikian data yang terekam adalah data yang benar-benar valid. Gabungan semua teknik pengumpulan data yang peneliti gunakan berfungsi sebagai teknik trianggulasi. Yaitu suatu cara atau teknik untuk uji validitas dalam penelitian kualitatif (Tanzeh, 2009: 7).

\section{Penentuan Populasi dan Sample.}

Popolusi dalam penelitian ini adalah jamaah masjid Nurus Sa'adah, yang selalu mengikuti kegiatan salat jamaah, sementara samplenya peneliti menggunakan porpusive sample, yaitu kepada para jamaah yang mempunyai aktifitas relative tinggi, yaitu sebanyak 20 responden, yang tersebar dalam enam RT. Kelebihan dari teknik ini adalah sedikit kasus yang diteliti secara secara mendalam memberikan banyak pemahaman tentang topik yang diteli (Sukmadinata, 2007: 101-102).

\section{Teknik Analisis Data}

Analisis data yang digunakan dalam penelitian ini adalah analisis deskriptif dengan mencoba memaparkan data yang telah diseleksi secara reduktif dan menggambar fenomena yang terjadi dengan mencoba memahami berdasarkan teori-teori yang ada baik dari teori sosiologi agama, maupun teori yang berkaitan dengan dinamika sosial dan motivasi sosial. Dari penelitian ini diharapkan 
akan memberikan kontribusi atau nilai kemanfaatan pada dua aspek, yaitu signifikansi keilmuan (signikansi ilmiah) dan juga signifikasi sosial, atau manfaat sosial dan manfaat praktis. Dua istilah signikansi ilmiah dan signifikansi sosial ini di kenal pula dengan signifikansi teoritis dan signikansi praktis.

\section{Perdirian, Perkembangan dan aktivitas Masjid Nurus Sa'adah}

Sejarah Berdirinya

Masjid di kompleks perumahan Dliko Indah ini selesai dibangun pada tanggal 9 Januari 1987. Masjid ini kemudiah di beri nama Masjid Nurus Sa'adah, yang artinya "cahaya kebahagiaan" dan nama ini disepakati seluruh panitia pembangunan masjid. Masjid ini di bangunan atas bantuan dari PP Muhammadiyah sebesar Rp.10.000.000,- dan infaq warga Dliko Indah dan sekitarnya sebesar Rp.3.500.000,- (Bulletin Lokal, edisi 5 Tahun 2009: 2). Mesjid Nurus Sa'adah, berdiri di atas lahan tanah di kompleks perumahan Dliko indah seluas $414 \mathrm{~m} 2$. Dalam perkembangannya masjid ini telah menambah lahan tanah seluas kurang lebih $600 \mathrm{~m} 2$, yang direncanakan untuk pembangunan Islamic Centre di kompleks masjid Nurus Sa'adah, dan saat ini tahun 2015 dalam proses awal pembangunannya.

Sampai kurang lebih satu tahun setelah selesainya pembangunannya masjid ini belum memiliki pengurus Takmir. Baru kemudian pada tanggal 20 Mei 1988 dibentuklah takmir melalui musyawarah Panitya Pembangunan Masjid. Dari musyawarah itu terbentuklah susunan Pengurus takmir Masjid dan terpilihlah Indriyatno (Ketu Umum), Dr. M. Zulfa (Ketua I), J. Nuryono, SH (Ketua II).

\section{Aktifitas Ibadah Mahdhah}

Aktifitas keagamaan yang termasuk ibadah mahdhah di masjid Nurus Sa'adah ini meliputi jamaah salat subuh, dzuhur, ashar, maghrib dan isya'. Jamaah subuh rata-rata diikuti kurang lebih 70 jamaah, yang secara rutin selalu hadir. Pada salat subuh ini yang paling banyak jumlah jamaahnya adalah pada hari ahad, kurang lebih 
sekitar 100 orang karena dilanjutkan dengan kuliah subuh yang diisi oleh para dosen IAIN Salatiga. Pengajian atau kuliah siubuh ini dengan tema beragam, dan sering menggunakan media LCD. Metode dengan pemaparan power point lewat LCD ini cukup menimbulkan antusiasme para jamaah. Tema-tema yang pernah disampaikan diantaranya meliputi: dahsyatnya Istighfar, berobat dengan do'a, Sabar, syukur, bahkan juga al-qur'an dan science, kejadian manusia dan sebagainya. Secara umum, tema-tema itu disampaikan lewat power point yang cukup menarik perhatian para jamaah. Kuliah ahad subuh ini dilanjutkan dengan minuman hangat dan sarapan pagi, sehingga menambah semaraknya suasana ahad pagi.

Kegiatan jamaah salat dzuhur adalah jamaah yang jumlahnya sangat sedikit, begitu pula salat jamaah 'ashar, walau demikian bisa mencapai sekitar 20 orang. Hal itu karena masa-masa salat dhuhur dan 'ashar adalah masa-masa kerja, sehingga warga masih kegiatan di tempat kerja masing-masing, sehingga yang mengikuti jama'ah salat dhuhur dan 'ashar adalah para pensiunan dan orang-orang yang tidak punya kerja di kantor. Di samping salat jamaah rawatib di Masjid Nurus Sa'adah, diselenggarakan salat lail atau tahajud, yang dimulai jam 03.15 sampai menjelang salat shubuh, namun jamaahnya masih sangat sedikit, yaitu kurang lebih sekitar 20 orang, yang terdiri dari bapak-bapak dan ibu-ibu.

Sementara untuk kegiatan salat tarawih di bulan ramadlan biasanya diikuti oleh kurang lebih sekitar 200 orang. Namun demikian pada akhir bulan biasanya menyusut sehingga sekitar 125 sampai dengan 150 orang. Pada moment-moment tertentu diselenggrakan pula salat jamaah, seperti salat Idul Fitri, Idul Adha, salat gerhana matahari maupun gerhana bulan, dan salat hajat setiap memasuki tahun baru hijriah.

Aktifitas keagamaan yang berkaitan dengan ibadah mahdhah meliputi Shalat rawatib, shalat sunnat rawatib, shalat tarawih shalat idul Fithri dan salat idul Adha. Kegiatan ibadah ghairu mahdhah yang meliputi: Pengajian rutin setiap jum'at sore dan kuliah subuh setiap hari ahad setelah salat subuh secara rutin. Awalnya ceramahceramah keagamaan baru sebatas pada momentum hari-hari besar keagamaan seperti pada peringatan Maulid Nabi dan Isra' Mi'raj, 
dan pada bulan romadlon itupun tidak diselenggarakan tiap hari. Baru kemudian setelah pada bulan Ramadhan tahun 1995, secara rutin diadakan pengajian ibu-ibu pada jumat sore. Pengajian ibuibu ini kemudian dikembangkan dengan melibatkan bapak-bapak. Pada pengajian rutin jumat sore ini kemudian menghadirkan dosen IAIN dengan diprakarsai oleh takmir yang kebetulan salah satu unsur pengurusnya adalah dosen IAIN yaitu M. Zulfa. Keterlibatan para dosen IAIN baik pada pengajian rutin maupun kajian-kajian rutin tiap malam di bulan romadlon bakdal isya' ini akhirnya berkembang pengajian atau kuliah subuh setiap hariahad, yangkemudian dilanjutkan makan pagi atau sarapan. Pada kajian ahad subuh ini semakin nampak perkembangannya, bukan saja diikuti oleh jamaan Masjid Nurus Sa'adah tapi juga jamaah lain yang ada disekitar perumahan Dliko Indah. Antara lain dari jamah Masjid Syuhada di perumahan Sehati dan beberapa musholla yang ada disekitarnya. Jamaah pengajian ahad subuh ini kini telah mencapai sejumlah 100 orang.

Dari hasil wawancara, pada umumnya para masyarakat muslim disekitar masjid, menyatakan bahwa mereka sekarang merasa lebih aktif dan senang mengikuti kegiatan yang diselenggarakan oleh takmir masid, terutama yang berkaitan dengan pembinaan keagamaan. Dari 20 orang yang sempat diwawancarai mereka merasa, senang dan tenang dalam mengikuti kegiatan pengajian baik pada jum'at sore maupun ahad setelah selesai solat subuh. Beberapa jamaah yang terbilang tokoh masyarakat dan masyarakat pada umumnya merasa senang mendengarkan penceramah dari IAIN Salatiga yang selalu bergantian dan memberikan materi pengajian yang bermutu serta enak di dengar, dicerna dan didirakan. Merekapun juga mengatakan dengan tampilan penyajian yang menggunakan media elektronik seperti LCD dapat mudah diterima dan mengasyikkan. Mereka merasa mendapat dorongan untuk lebih meningkatkan semangat beragama, baik peningkatan ibadah mahdhah maupun amliah social. Mereka merasa ikhlas membantu dan memberikan sumbangan ataupun infaq untuk keperluan pembangunan masjid.

Hal ini terbukti dengan lancarnya wakaf bersam untuk memebeli tanah seluas $600 \mathrm{M} 2$ yang dapat terbeli oleh takmir masjid Nurus Sa'adah hanya dalam waktu kurang dari 1 bulan. Kemudian dilanjutkan memberikan bantuan dana untuk pembaangunan Islamic 
Centre secara suka rela dan semangat untuk terwujudnya Islamic Centre. Kemudian yang secara rutin para jama'ah mengeluarkan dana untuk jamuan makan pagi setiap minggu sekali dalam pengajian rutin bakda subuh. Sodaqoh ini nampaknya didasari semangat fastabiqul khirat, hal ini adanya bukti bahwa mereka yang ingin sodaqoh untuk member jamuan makan pagi ini harus antri tiga sampai empat minggu. Semangat berinfaq dan berzakat ataupun ibadah-ibadah lainnya seperti berqurban dari tahun ke tahun semakin meningkat. Kondisi amal ibadah mahdhah dan ibadah sosial lainnya, secara umum boleh dikatakan semakin meningkat dari tahun ke tahun. Bagi suatu perumahan yang hanya terdiri satu RW dengan enam RT, relatif cukup besar apabila setiap Idul Adha jamaah masjid Nurus Sa'adah dapat memotong 9 (sembilan) ekor sapi dan sekitar 30 ekor kambing. Sementara untuk setiap Idul Fitri rata-rata sekitar 11 juta rupiah untuk perolehan zakat fitrah dan sekitar 28 juta untuk zakat mal. Sementara distribusinya terbagi ke fakir miskin dan anak-anak yatim serta panti asuhan, dan anak-anak sekolah-sekolah MI yang tidak mampu.

\section{Aktifitas Sosial Keagamaan}

1. Zakat Fitrah dan Zakat Maal

Mengenai kegiatan kegiatan Zakat Fitrah, Masjid Nurus Sa'adah selalu menyelenggarakan kegiatan penerimaan dan penyaluran Zakat Fitrah. Penerimaan Zakat Fitrah setiap tahunnya rata-rata berkisar Rp. 10.625.000. Sementara untuk Zakat Maal berkisar Rp.28.155.000,- Sehingga total mencapai Rp.38.780.000 (data pada tahun 2013). Sementara tahun 2014 total zakat fitrah dan zakat maal sejumlah Rp.32.255.000 agak menurun dibanding tahun 2013, hal itu disebabkan pada tahun itu oleh para Muzakki di salurkan ke kampungnya masing-masing, dan ada yang langsung disampaikan kepada Panti Asuhan yang ada disekitar Salatiga.

2. Penyembelihan Hewan Qurban.

Penyembelihan hewan qurban, selalu diselenggarakan tiap tahun, dan kini jumlah hewan yang dipotong rata-rata sekitar 9 
ekor sapid an 30 ekor kambing. Jumlah hewan qurban tersebut semuanya merupakan pengurban jamaah masjid Nurus Sa'adah, atau warga Dliko Indah yang tergabung dalam satu RW. (RW 11 Kelurahan Blotongan) Kecamatan Sidorejo. Hewan qurban sebanyak itu untuk satu RW termasuk jumlah yang cukup tinggi, bila disbanding dengan RW-RW lainnya sekitar Salatiga. Diakui umum bahwa kesadaran berqurban jamaah masjid Nurus Sa'adah cukup tinggi. Kecuali itu distribusi pembagian daging qurban cukup luas, bahkan memasuki wilayah Kab. Semarang (Kecamatan Suruh, Tuntang dan Getasan). Cara penyalurannya menggunakan dua cara, yaitu pendistribusian hewan yang masih hidup/belum dipotong, yaitu semua kambing disalurkan ke daerah-daerah yang mebutuhkan. Dan penyaluran berupa daging sapi ke wilayah-wilayah yang dipandang memerlukan, baik memenuhi permintaan tertulis, maupun pertimbangan dari hasil pengamatan.

3. Penyelengaraan Manasik dan Pemberangkatan Jamaah haji

Pada setiap menjelang musim haji, Takmir masjid Nurus Sa'adah selalu menyelenggaraka Manasik Haji bagi calon Jama’ah Haji. Mereka tidak dipungut beaya, bahkan Takmir membantu penyelenggaraan pembarangkatan haji (Walimatus Safar) secara bersama. Penyelenggaraan Walimatus Safar secara bersama-sama semua Jalon Haji ini, selalu dilakukan menjelang keberangkatan Haji. Hal ini dilakukan untuk meringankan beban para jamaah dalam melaksanakan Walimatus Safar, disbanding bila masingmasing calon jama'ah menyelenggarakan secara mandiri. Untuk tamu undangan sekitar 200 sampai dengan 300, maka jamuan atau konsumsi yang harus dikeluarkan oleh para Calon Jamaah menjadi sangat ringan karena dipikul bersama oleh sejumlah Calon Jama'ah Haji. Disamping itu Takmir juga membantu mempersiapkan kepanitiaannya yang terdiri dari para pengurus Takmir dan warga setempat, untuk lancarnya acara Walimatus Safar.

4. Aktivitas Syiar Islam: Peringatan Hari Besar Islam

Pada momentum Hari-Hari Besar Islam, Masjid Nurus Sa'adah sering mengadakan kegiatan seremonial memperingati 
dengan acara utama ceramah pengajian sesuai dengan tema peringatannya. Peringatan itu meliputi Isra' Mi'raj, Maulud Nabi, Nuzulul Qur'an, Hari Raya Qurban dan Halal bi Halal. Dalam mengadakan peringatan itu pemberi ceramah adalah dosen IAIN dan sesekali kadang dari luar IAIN. Pada peringatan itu kecuali ceramah agama, kadang juga diserta dengan acara tambahan dari pementasan anak-anak dan remaja.

\section{Pembangunan dan Pengembangan Masjid}

Selama didirikannya masjid atau semenjak tahun 1987, telah mengalami dua kali renovasi dan pengembangan, karena jumlah jama'ah yang terus berkembang. Dan selama renovasi pengembangan masjid, dana yang dibutuhkan selalu bersumber dari dana para jama'ah, walaupun pernah sekali mendapat tambahan dana Pemerintah Propinsi Jawa Tengah sebesar Rp.15.000.000,pada tahun 2002. Kesadaran masyarakat untuk mendukung pembangunan masjid Nurus Sa'adah ini memang cukup tinggi, karena setiap adanya perbaikan dan peningkatan bangunan selalu didukung secara baik oleh para warga Dliko Indah yang beragama Islam. Ketua Takmir bapak Indriyatno pada awalnya ragu terhadap kemungkinan dukungan para jama'ah. Tetapi setelah diumumkan dan diinformasikan kepada para jama'ah, ternyata keterlibatannya cukup baik. Dukungan itu tidak hanya oleh para jama'ah tetapi juga atas praarsa jamaah, banyak para sudara dan familinya juga ikut membantu (Wawancara dengan ketua Takmir Masjid Nurus Sa'adah, 20 Februari 2015). Hal itu bisa ditunjukkan bahwa dalam waktu yang relative singkat (kurang dari satu bulan), jama'ah mampu memberikan kontribusi atau infaq pembelian tanah $600 \mathrm{M} 2$, untuk pengembangan fungsi masjid, sebagai pusat kegiatan social dan pendidikan atau Islamic Centre.

Sebelum melaksanakan pembangunan Islamic Centre, Takmir masjid dan Jama'ah melakukan studi banding atau kajian ke Masjid Jogokariyan Jogjakarta. Ternyat kunjungan ke Masjid Jogokariyan tersebut membawa dampak yang sangat positif. Artinya, sepulang dari kunjungan itu Takmir dan Jama'ah Nurus Sa'adah mempunyai semangat untuk berniat menambah bangunan bagi kepentingan 
Pendidikan, Kesehatan dan Sosial yang berwujud Islamic Centre. Sehingga dalam waktu awal terkumpul uang untuk pembelian tanah seharga 180 juta rupiah, dan modal awal pembangunan sekitar 200 juta rupiah lebih. Saat ini sudah mulai pembangunan tahap awal, atau unit I dua lantai, dan saat penulisan laporan penelitian ini pembangunan unit I baru saja selesai pengecoran atau dag untuk lantai atas.

Latar belakang pengembangan Masjid Nurus Sa'adah menjadi kompleks Masjid dan Islamic Centre, sebagaimana penjelasan Panitia Pembangunan yaitu bapak Muchib, SE dan bapak Indarto adalah sebagai berikut:

1. Mayoritas penduduk Dliko Indah Blotongan ber agama Islam (kurang lebih 70\%)

2. Peningkatan jama'ah masjid dari waktu ke waktu

3. Keinginan Takmir Masjid untuk menyatukan Ibadah Mahdhah dan aktifitas Ibadah Ghairu mahdhah dalam satu kompleks.

4. Dampak kemajuan ilmu pengetahuan dan teknologi beserta efek positif dan negatifnya terutama terhadap generasi mudanya. Oleh karena itu kepada generasi muda perlu dibekali ilmu dan akhlaq, agar menjadi generasi muda yang memiliki pribadi yang beriman, bertaqwa, cerdas, terampil dan mandiri.

5. Memupuk ghirah dan semngat jamaah dalam mengembangkan fungsi masjid.

Sementara menurut Takmir dan Panitia Pembangunan Islamic Centre ini bertujuan untuk :

1. Menjadikan masjid sebagai pusat kegiatan masyarakat (centre of activity)

2. Menjadikan Masjid sebagai tempat rekreasi rohani jama'ah.

3. Menjadikan Masjid sebagai sarana pencerahan dan pendidikan Agama Islam.

4. Menjadikan Masjid sebagai sarana pelatihan dan pengkaderan generasi muda (training kepemimpinan, manajemen organisasi, kewira usahaan dan sebagainya) 
5. Menjadikan Masjid sebagai pusat kegiatan RemajMasjid untuk mengembangkan aktifitas keilmuan, ketrampilan dan pengembangan diri dan bakat.

6. Menjadikan Masjid sebagai tempat merujuk berbagai persoalan masyarakat.

7. Menjadikan Masjid sebagai pusat kesehatan masyarakat dengan metoda pengobatan yang Islami.

\section{Analisis}

\section{Peranan Penceramah sebagi Motivator}

Dari hasil wawancara seluruh responden menyatakan bahwa ceramah-ceramah atau pengajian yang diberikan oleh para dosen IAIN, sangat menambah ilmu pengetahuan khususnaya bidang agama. Mereka sangat merasakan materi-meteri pengajian yang disampaikan sangatmemberikan pencerahan, sehinggamenimbulkan motivasi para jamaah untuk lebih meningkatkan penghayatan dan pengamalan agama. Dulu saya kurang dalam melaaksanakan salat jamaah atau mengikuti pengajian-pengajian, tetapi sekarang saya hampir tidak pernah absen dalam melaksanakan salat jamaah. (wawancara dengan bapak Bg, bapak Jyd, BbS, bapak YsM, bapak Syj, bapak Mhd, bapak Mh, bapak Skn, bapak PtS pada tanggal 2025 Maret 2015). Dari kenyataan ini, dapat disimpulkan bahwa para penceramah telah mengubah sikap keberagamaan umat, sehingga mereka dengan sukarela memberikan infaq fikiran, tenaga bahkan harta untuk kemakmuran dan perkembangan masjid. Sehingga lewat penceramah dari IAIN yang dilakukan secara rutin terjadwal dan sistemtis, telah terjadi transformasi keilmuan khususnya ilmu agama. Agama lewat penceramah dari IAIN bermakna sebagai edukator bagi masyarakat, khususnya warga muslim atau para jamaah. Sebagaimana diungkapkan oleh sosiolog D. Hendro Puspito (1983) bahwa Agama menyampaikan ajarannya dengan perantaraan petugas-petugasnya baik di dalam upacara (perayaan) keagamaan, khotbah, renungan/ meditasi (dzikir), pendalaman rohani (pen.: ibadah) dan lain-lain, maupun di luar perayaan liturgis (pen.: silaturrahmi dan kegiatan lain seperti hajatan dsb.). 
Realitas di atas dapat disimpulkan bahwa dengan berbasis masjid, motivasi untuk mewujudkan pribadi-pribadi yang unggul dan berkualitas khususnya dalam amaliah keagaaman, dapat dilakukan dengan lebih efektif. Kenyataan ini dapat dilihat bahwa penceramah dari IAIN telah mampu menunjukkan hal itu, yaitu memotivasi terhadap para jamaah di Masjid Nurus Sa'adah untuk melakaukan amaliah sosial dan keagamaan, dengan ditunjukkannya pembelihan tanah secara swadaya murni dan proses pembangunan Islamic Centre, yang saat ini sudah mulai pembangunannya.

Seperti yang telah diungkap di depan bahwa semua responden, yang merupakan jamaah Masjid Nurus Sa'adah secara umum dapat difahami bahwa mereka telah merasa tercerahkan oleh para penceramah yang pada intinya terdiri dari para dosen IAIN Salatiga, mereka merasa merasa mendapat pengetahuan dan ilmu keagamaan yang lebih banyak dengan mengikuti kegiatan pengajaian-pengajian rutin setiap hari jum'at sore dan ahad subuh, bahkan kini mereka merasa tenang dan tentram dengan mengikuti berbagai macam aktifitas masjid, baik itu berupa rutinitas salat jamaah, maupun tausiyah-tausiyah keagaamn oleh patra penceramah. Artinya, mereka telah merasakan itu semua karena akibat proses trasformasi ke ilmuan keagamaan oleh para penceramah.

Menurut sosiolog, fungsi transformatif yang diklakukan dalam aktifitas keagamaan berarti mengubah bentuk kehidupan masyarakat lama dalam bentuk kehidupan baru, (Hendropuspito, 1983: 56). Nilai-nilai yang telah diperoleh oleh para jamaah itu telah mengubah kesetiaan jamaah dari kebiasaan lama ke dalam kebiasaan baru dan membentuk kepribadian. Hal itu dapat diidentifikasi para jamaah yang dulunya tidak atau jarang sekali berjamaah kini telah rajin mengikuti salat wajib dengan berjamaah, yang dulu jarang sekali mengikuti pengajian, kini telah banyak dan selalu mengikuti pengajian-pengajianm rutin yang diselenggarakan oleh Takmir Masjid. Sebagai contoh yang sederhana dalam fenomena ini dapat dilihat kalau dulu sebelum mendapat pencerahan, orang cenderung mudah konflik atau mudah renggang dengan sesama tetangga, kini setelah pencerahan terjadi fenomena rukun, saling komunikasi dan silaturrahmi, bahkan kebersamaan dan akrab selalu dan sering terlihat diantara anggota masyarakat, terlebih dalam acara-acara kegiatan 
keagamaan baik ibadah mahdhah, maupun ibadah ghairu mahdhah, terlebih dalam keterlibatan kepanitiaan. Kebersamaan itu tterlihat dalam acara-acara pengajian-pengajian, penerimaan dan penyaluran zakat mal dan fitrah, penyembelihan dan penyaluran hewan qurban, peringatan-peringatan hari-hari besar Islam, kegiatan pelatihan manasik haji maupun walimatussafar, maupun walimatul urusy. Dari realitas ini dapat disimpulkan bahwa proses transformasi atau perubahan kehidupan ke arah yang lebih positif dan lebih baik sangat baik dilakukan dengan media masjid sebagai basis pembinaa umat. Kini jamaah Masjid Nurus Sa'adah telah mewujudkan kehidupan bersyarakat yang lebih damai, rukun dan penuh keakraban, bukan saja pada kegiatan ibadah mahdhah tetapi juga pada kegiatan sosial kemasyarakatan.

\section{Kesadaran Religiusitas Jamaah}

Berbagai kegiatan keagamaan baik berupa peningkatan kualitas ibadah mahdhah maupun piningkatan sosial keagamaan dan sosial umum kemasyarakatan telah diwujudkan oleh jamaah Masjid Nurus Sa'adah. Hal itu diakui oleh para responden bahwa ajaran agama menegaskan sebaik-baiknya manusia adalah yang memberikan manfaat terhadap lingkungannya. Artinya bahwa dengan kesadaran yang tinggi, mereka para jamaah telah mencoba mengamalkan ajaran agama untuk menjadi "manusia yang baik" yang berguna bagi lingkungannya. Ini berarti Takmir dan Penceramah yang pada umumnya dari IAIN itu telah dapat mewujudkan kesadaran yang cukup tinggi terhadap para jamaah masjid Nurus Sa'adah untuk melakukan kegiatan yang baik yang bermanfaat bagi lingkungannya. Hal itu bisa dilihat kebersamaan mereka dalam melakukan salat jamaah secara rutin di masjid, kegiatan bersama dalam amaliah sosial lainnya seperti pembagian zakat, pembagaian hewan qurban, mewujudkan tanah dan bangunan Islamic Centre, layanan kesehatan gratis bagi masyarakat yang tidak mampu, layanan sembako murah pada moment-moment tertentu. Di samping itu membantu anakanak miskin untuk beaya pendidikan. Membantu para warga sekitar yang tidak mampu untukdengan memberikan modal, seperti misalnya perajin tempe, dan kegiatan sosial lainnya. 
Kesadaran yang tinggi yang diperlihatkan oleh para jamaah dan takmir Masjid Nurus Sa'adah dalam merealisasikan ajaran Islam merupakan perilaku dinamis masyarakat dalam beragama. Sebagaimana digambarkan oleh Comton dan Galaway yang mengetengahkan pendapat Lippit dan Westley dalam Social Work and Processes (1979:109) berpendapat, bahwa dinamika perilaku masyarakat yang membentuk kebudayaan khas yang memantulkan adalah karena kebutuhan yang sama akan tujuan yang hendak dicapai yang dikokohkan oleh hubungan fungsional dan pilihan social yang teruji serta generalisasi kepentingan yang lebih transformatif dan stabil untuk dijadikan norma-norma kehidupan dalam masyarakat (Saebani, 2007: 2).

Ajaranagamamemilikipengaruhyangbesardalammenyatukan persepsi kehidupan masyarakat tentang semua harapan hidup. Sebagai salah satu arah kehidupan sosial yang proses pemolaannya lebih sistematis dan mendarah daging. Dalam pemolaan, perilaku sosial agama memasuki hati nurani manusia sehingga akal pikiran utama mencari makna hidup belum sempurnan apabila substansi ajaran agama tidak dijadikan rujukan terpenting secara etimologis ataupun aksiologis (Hamka, 1989:13, dalam Saebani, 2007:2).

Kegiatan jamaah dan takmir dapat dipandang sebagai kegiatan yang cukup menarik untuk di cermati, betapa tidak para jamaah dan takmir telah mencurahkan perhatian yang penuh untuk terwujudnya Islamic Centre. Bukan saja mereka harus mengeluarkan dana untuk diinfaqkan, tetapi juga uapaya-upaya spiritual mereka lakukan diantaranya, salat lail atau tahajud yang dilakukan setiap malam ahad secara rutin, dan meningkatkan jamaah salat rawatib dengan rajin. Hal itu dilakukan dengan harapan agar Allah SWT mengabulkan permohonan mereka. Mereka cukup semangat menyebarkan informasi program-program masjid termasuk Pembangunan Islamic Centre kepada masyarakat luas di luar Warga Dliko Indah, termasuk kepada sanak sauadara, famili dan sahabatnya untuk ikut terlibat dalam membantu dana untuk terwujudkan bangunan Islamic Centre. 


\section{Kesimpulan.}

Dalam perjalanan sejarah Masjid Nurus Sa'adah (1987 sampai dengan sekarang, 2015), telah mengalami perkembangan,baik sebagai tempat ibadah umat Islam maupun sebagai pusat pembinaan masyarakat Dliko Indah dan sekitarnya. Kesadaran yang tinggi yang diperlihatkan oleh para jamaah dan takmir Masjid Nurus Sa'adah dalam merealisasikan ajaran Islam merupakan perilaku dinamis masyarakat dalam beragama. Berbagai kegiatan keagamaan baik berupa peningkatan kualitas ibadah mahdhah maupun piningkatan sosial keagamaan dan sosial umum kemasyarakatan telah diwujudkan oleh jamaah Masjid Nurus Sa'adah.

Secara umum dapat difahami bahwa para jama'ah Masjid Nurus Sa'adah telah merasa tercerahkan oleh para penceramah yang dihadirkan oleh pengurus masjid. Mereka merasa mendapat pengetahuan dan ilmu keagamaan yang lebih banyak dengan mengikuti kegiatan pengajaian-pengajian rutin setiap hari jum'at sore dan ahad subuh, bahkan kini mereka merasa tenang dan tentram dengan mengikuti berbagai macam aktifitas masjid, baik itu berupa rutinitas salat jamaah, maupun tausiyah-tausiyah keagamaan oleh patra penceramah.

Para jama'ah telah merasakan itu semua karena akibat proses trasformasi ilmu keagamaan yang mereka terima dari para penceramah. Hal itu diakui oleh seluruh responden jama'ah Masjid Nurussa'adah. Mereka sangat merasakan materi-meteri pengajian yang disampaikan sangat memberikan pencerahan, sehingga menimbulkan motivasi para jamaah untuk lebih meningkatkan penghayatan dan pengamalan agama. Dengan demikian, masjid sebagai basis pembinaan umat, telah dapat diwujudkan oleh Masjid Nurus Sa'adah.

\section{Daftar Pustaka.}

Agus, Bustanuddin. 2003. Sosiologi Agama, Padang, CV. Yakinku Futura.

Ayib, E, dkk, 2001. Anajemen Masjid, Petunjuk Praktis bagi Para Pengurus, Jakarta, Gema Insani Press. 
Gazalba, Sidi, 1989, Mesjid Pusat Ibadat dab Kebudayaan, Jakarta, 1989.

Hendropuspito, D, OC. 1983, Sosiologi Agama, Yogyakarta, Penerbit Kanisius, BPK Gunung Mulia,.

O'dea Thomas F. 1996, Sosiologi Agama Suatu Pengenalan Awal. 'terj." Tim Penerjamah Yasogama, Jakarta: PT. Raja Grafindo Persada.

Saebani Beni Ahmad. 2007. Sosiologi Agama, Kajian tentang Perilaku Institusional dalam Beragama Anggota Persis dan Nahdlatul Ulama, Bandung, PT Refika Aditama.

Sugiyono. 2010, Metode Penelitian Kuantitatif Kaulitatif dan R\&D, Bandung, Alfabeta.

Sukmadinata, Nana Syaodih. 2009. Metode Penelitian Pendidikan, Bandung, Rosdakarya.

Suprayogo, Imam Dan Tobroni, 2003. Metodologi Penelitian Sosial Agama, Bandung Rosdakarya. 